\title{
Neospora caninum: evaluation of vertical transmission in slaughtered dairy cows (Bos taurus)
}

\author{
Neospora caninum: avaliação da transmissão vertical em vacas leiteiras (Bos taurus) \\ César Augusto Barbosa de Macedo ${ }^{1}$; Madlaine Frigo Silveira Barbosa de Macedo ${ }^{1}$; Sergio Tosi Cardim²; \\ Milaine Cristiane Dantas Custódio Paiva²; Alessandra Taroda²; Luiz Daniel Barros²; \\ Ivo Alexandre Leme da Cunha²; Dauton Luiz Zulpo²; João Luis Garcia ${ }^{2 *}$ \\ ${ }^{1}$ Companhia Integrada de Desenvolvimento Agrícola de Santa Catarina, Presidente Getúlio, SC, Brasil \\ ${ }^{2}$ Departamento de Medicina Veterinária Preventiva, Universidade Estadual de Londrina - UEL, Londrina, PR, Brasil \\ Received February 1, 2012 \\ Accepted May 3, 2012
}

\begin{abstract}
Neospora caninum is a worldwide parasite recognized as one of the main parasites responsible for abortion in cattle. The objective of this study was to evaluate vertical transmission of $N$. caninum in dairy cows (Bos taurus) that were slaughtered at an abattoir in the state of Santa Catarina, southern Brazil. Blood samples (with and without EDTA) from 60 pregnant dairy cows and blood and tissue samples (brain, lung, heart and liver) from their fetuses were collected and used for PCR and serological evaluation. Blood samples from 60 non-pregnant cows were collected and used to detect antibodies. Anti-N. caninum antibodies were detected by indirect ELISA. Antibodies against $N$. caninum were observed in $41.6 \%(25 / 60)$ of the pregnant cows and in $43.3 \%(26 / 60)$ of the non-pregnant cows. Antibodies against the parasite were detected in sera from three fetuses (5.5\%). PCR analysis revealed that 3.3\% (2/60) of the cows and $6.6 \%(4 / 60)$ of the fetuses evaluated were positive for specific $N$. caninum primers. These positive fetuses were between 4-6 months of age. Therefore, considering PCR and serological tests to be indicative of vertical transmission in fetuses, $11.6 \%(7 / 60)$ of the fetuses were infected by N. caninum during gestation.
\end{abstract}

Keywords: Neospora caninum, dairy cattle, vertical transmission, Bos taurus.

\section{Resumo}

Neospora caninum é um parasita de distribuição mundial reconhecido como um dentre os principais parasitas, responsável por abortamento em bovinos. O objetivo deste estudo foi avaliar a transmissáo vertical de $N$. caninum em vacas leiteiras (Bos taurus) que foram submetidas ao abate em matadouro no Estado de Santa Catarina, sul do Brasil. Sangue (com e sem EDTA) de 60 vacas leiteiras prenhas e amostras de sangue e tecidos (cérebro, pulmão, coração e fígado) de seus fetos foram coletados e utilizados para PCR e avaliação sorológica. Amostras de sangue de 60 vacas não-gestantes foram obtidas e utilizadas para detecção de anticorpos. A detecção de anticorpos séricos anti- $N$. caninum foi avaliada pelo ELISA-teste indireto. Anticorpos anti-N. caninum foram observados em 41,6\% (25/60) das vacas prenhas e em 43,3\% $(26 / 60)$ das vacas não-gestantes. Três fetos $(5,5 \%)$ foram soros positivos para $N$. caninum. Análise pela PCR revelou que $3,3 \%$ (2/60) das vacas e 6,6\% (4/60) dos fetos avaliados foram positivos para $N$. caninum. As idades dos fetos positivos eram de 4 a 6 meses. Portanto, considerando a PCR e a sorologia como indicativo de transmissáo vertical em fetos, 11,6\% (7/60) dos fetos foram infectados por $N$. caninum durante a gestaçáo.

Palavras-chaves: Neospora caninum, vacas leiteiras, transmissão vertical, Bos taurus.

\section{Introduction}

Neospora caninum is a protozoan parasite that is distributed worldwide and is a major cause of abortion in cattle (DUBEY; SCHARES, 2006). Animals may be infected via three routes: ingestion of sporulated oocysts; transmission from dams to

\footnotetext{
*Corresponding author: João Luis Garcia

Universidade Estadual de Londrina - UEL, CP 6001, CEP 86050-970,

Londrina, PR, Brasil

e-mail: jlgarcia@uel.br
}

fetuses (vertical); and through meat containing tissue cysts. Cattle, as herbivorous animals, are infected via the first and second routes. In dairy herds, transmission principally occurs vertically (SCHARES et al., 1998; BARTELS et al., 2007). Vertical transmission can occur throughout the gestation period; however, abortions are most prevalent at 3 to 6 months of pregnancy (DUBEY; SCHARES, 2006). However, female calves can be born infected without any sign of infection and can keep the parasite 
in their tissue while they are raised, such that when they become pregnant, they may transmit the parasite to their offspring. This type of transmission is known as endogenous transplacental infection (TREES; WILLIAMS, 2005).

Neosporosis has been described as an important cause of abortion in southern Brazil (CORBELLINI et al., 2001, 2002; LOCATELLI-DITTRICH et al., 2001). Locatelli-Dittrich et al. (2001) reported that the abortion risk in $N$. caninum-seropositive dairy cows was four times higher than in seronegative dairy cows. Corbellini et al. (2002) used both histopathological and serum sample examination from bovine aborted fetuses, and described a high rate of occurrence of $N$. caninum as the cause of abortion throughout the state of Rio Grande do Sul.

Although several studies relating to neosporosis among dairy cattle have been conducted, the documentation of vertical transmission in Brazilian herds remains inadequate. Thus, the aim of the present study was to evaluate anti- $N$. caninum antibody occurrence in serum samples, and vertical transmission of $N$. caninum from dairy cows slaughtered at an abattoir located in the southern region of Brazil.

\section{Materials and Methods}

The 120 samples were obtained from pregnant and non-pregnant dairy cows (Bos taurus) and their respective fetuses at an abattoir located in the municipality of Presidente Getúlio, state of Santa Catarina, southern Brazil during 2010 year. The present study was approved by the Animal Ethics Committee of the State University of Londrina (N. 018/2009).

Antibodies against $N$. caninum were detected by means of the HerdCheck Neospora caninum Antibody Test Kit (Idexx Laboratories). Serum samples from the cows were diluted at the ratio of 1:100, and serum from fetuses at 1:25.

Blood samples with EDTA were collected individually in sterile tubes from the pregnant cows after they had been bled along the inspection line (during bleeding of the animals) and from their fetuses by means of cardiac puncture. The white blood cells were separated by centrifugation ( $550 \mathrm{~g}$ for 10 minutes), and were used for DNA extraction and subsequent PCR analyses. The uterus of the dams was obtained individually with the fetuses inside. Each uterine horn containing the fetuses was aseptically opened, the fetuses were taken out from the uterus, and organ material was collected on individual sterilized Petri plates. At the laboratory, approximately $10 \mathrm{~g}$ of tissue fragments (brain and myocardium) were collected from fetuses $\geq 3$ months of age, while similar tissue fragments $(10 \mathrm{~g})$ for fetuses $\leq 2$ months were pooled for DNA extraction. The tissue samples were homogenized with $10 \mathrm{~mL}$ of saline solution $(0.14 \mathrm{M}$ of $\mathrm{NaCl})$, after which the homogenate was filtered, and $2 \mathrm{~mL}$ were used for DNA extraction.

The DNA extraction was performed using the DNeasy Blood \& Tissue Kit (QIAGEN Sample \& Assay Technologies, Brazil), following the manufacturer's recommendations. PCR analyses were performed as previously described (MARQUES et al., 2011). Amplification of $N$. caninum DNA was done by using the Np21 and Np6 primers (MULLER et al., 1996). The PCR cycle was performed on a mixture (final volume of $25 \mathrm{~mL}$ ) containing $5 \mathrm{~mL}$ of extracted DNA admixed with $20 \mathrm{~mL}$ of a solution containing $1.0 \mathrm{mM}$ of each primer, $100 \mathrm{mM}$ of dNTP (Invitrogen, Life Technologies, USA), $60 \mathrm{mM}$ of Tris- $\mathrm{HCl}$ (pH 9.0), $15 \mathrm{mM}$ of $\left(\mathrm{NH}_{4}\right)_{2} \mathrm{SO}_{4}, 1.5 \mathrm{mM}$ of $\mathrm{MgCl}_{2}$, and $0.5 \mathrm{U}$ of Taq DNA polymerase (Invitrogen Life Technologies, USA). Amplification of parasitic genomic DNA was done over 35 cycles in a PTC-100 thermocycler (MJ-Research), using the following cycling conditions: 5 minutes at $94^{\circ} \mathrm{C}$, followed by 35 cycles of 30 seconds at $94^{\circ} \mathrm{C}, 30$ seconds at $65^{\circ} \mathrm{C}$ and 60 seconds at $72{ }^{\circ} \mathrm{C}$; the $35^{\text {th }}$ cycle was followed by a final extension of 7 minutes at $72^{\circ} \mathrm{C}$. Aliquots from each PCR were viewed by means of electrophoresis on $2 \%$ agarose gel. For positive controls, DNA extracted from tachyzoites of the NC-1 strain $\left(10^{6} / \mathrm{mL}\right)$ of $N$. caninum, diluted in TE buffer, were used. The negative control consisted of commercially prepared water samples without $N$. caninum. One positive and one negative control was included in each assay.

All variables were analyzed by means of the chi-square test $\left(\chi^{2}\right)$, with Yates correction, using the Epi Info software (CDC, version 6.04b). $P$-values $\leq 0.05$ were taken to be significant.

\section{Results}

The serological results for $N$. caninum are presented in Table 1 . Out of a total of 120 cows, samples from 51 (42.5\%) reacted positively to $N$. caninum. Positive seroreactivity to $N$. caninum occurred in samples from $41.6 \%(25 / 60)$ of the pregnant cows, while the positivity rate among non-pregnant animals was $43.3 \%$ $(26 / 60)$; these values were not statistically different $(p=1.0)$. There was no statistical difference in relation to the breed of cattle (Table 1, p = 1.0). When the period of gestation was evaluated, there were no differences in the prevalence of $N$. caninum relative to the first $(50 \%)$, second $(35.7 \%)$ or third trimester $(44.4 \%)$. Considering that almost all of the cows were more than four years old (116 animals), no comparisons regarding prevalence and proportionality with age were calculated.

The average optical density (OD) of the positive samples obtained from the pregnant animals was $1.64 \pm 0.92$, compared with $1.82 \pm 0.1 .05$ among their non-pregnant counterparts (Table 2). In relation to the period of gestation, the mean OD was $1.18 \pm 0.89$ for the first, $2.16 \pm 0.90$ for the second and $1.28 \pm 0.83$ for the

Table 1. Demonstration of the association between the variables studied and the presence of antibodies for Neospora caninum in slaughtered pregnant dairy cows (Bos taurus), in state of Santa Catarina, 2010.

\begin{tabular}{ccccc}
\hline Variables & $\begin{array}{c}\text { Positive } \\
(\%)\end{array}$ & $\begin{array}{c}\text { Negative } \\
(\%)\end{array}$ & $\begin{array}{c}\text { Total } \\
(\%)\end{array}$ & $P$ \\
\hline Neospora & & & & \\
Cows & $25(41.6)$ & $35(58.4)$ & $60(50)$ & $1.0^{1}$ \\
Pregnant & $26(43.3)$ & $34(56.7)$ & $60(50)$ & \\
Non-pregnant & $51(42.5)$ & $69(57.5)$ & $120(100)$ & \\
Trimester of gestation & & & & \\
First & $7(50.0)$ & $7(50.0)$ & $14(23.3)$ & \\
Second & $10(35.7)$ & $18(64.3)$ & $28(46.7)$ & $0.87^{1}$ \\
Third & $8(44.4)$ & $10(55.6)$ & $18(30.0)$ & \\
\hline
\end{tabular}

${ }^{1}$ Chi-square with Yates correction. \% percentage. 
Table 2. Outcomes regarding Neospora caninum infection in slaughtered pregnant dairy cows (Bos taurus) and their fetuses, in state of Santa Catarina, 2010.

\begin{tabular}{|c|c|c|c|c|c|c|}
\hline \multirow{3}{*}{ Cow no. } & \multicolumn{2}{|c|}{ ELISA $^{1}$} & \multirow{3}{*}{$\begin{array}{l}\text { Age of fetus } \\
\text { (months) }\end{array}$} & \multicolumn{3}{|c|}{ PCR } \\
\hline & \multirow{2}{*}{ Cow } & \multirow{2}{*}{ Fetus } & & \multirow{2}{*}{$\begin{array}{l}\text { Cows } \\
\text { Blood } \\
\end{array}$} & \multicolumn{2}{|c|}{ Fetuses* } \\
\hline & & & & & Brain & Myocardium \\
\hline 2 & 2.18 & $\mathrm{~N}$ & 4 & - & - & - \\
\hline 13 & 1.83 & $\mathrm{NO}$ & 1 & + & - & - \\
\hline 25 & 2.25 & $\mathrm{~N}$ & 7 & - & - & - \\
\hline 26 & 2.17 & $\mathrm{~N}$ & 3 & - & - & - \\
\hline 28 & 0.55 & $\mathrm{~N}$ & 6 & - & - & - \\
\hline 53 & 3.05 & $\mathrm{~N}$ & 6 & - & - & - \\
\hline 54 & 0.6 & $\mathrm{~N}$ & 7 & - & - & - \\
\hline 58 & 1.13 & 3.3 & 8 & - & - & - \\
\hline 62 & 0.59 & $\mathrm{NO}$ & 1 & - & - & - \\
\hline 64 & 2.48 & $\mathrm{~N}$ & 5 & - & - & - \\
\hline 74 & $\mathrm{~N}$ & $\mathrm{~N}$ & 6 & - & - & + \\
\hline 78 & 2.7 & $\mathrm{~N}$ & 5 & - & - & - \\
\hline 79 & 2.48 & $\mathrm{~N}$ & 3 & - & - & - \\
\hline 85 & 2.7 & $\mathrm{~N}$ & 5 & - & - & - \\
\hline 87 & $\mathrm{~N}$ & $\mathrm{~N}$ & 7 & - & + & - \\
\hline 91 & 0.73 & $\mathrm{~N}$ & 8 & - & - & - \\
\hline 92 & 2.54 & $\mathrm{~N}$ & 4 & - & - & - \\
\hline 95 & $\mathrm{~N}$ & $\mathrm{NO}$ & 2 & + & - & - \\
\hline 97 & 0.74 & $\mathrm{NO}$ & 2 & - & - & - \\
\hline 105 & 2.02 & $\mathrm{~N}$ & 7 & - & - & - \\
\hline 111 & $\mathrm{~N}$ & $\mathrm{~N}$ & 3 & - & + & - \\
\hline 113 & 0.62 & $\mathrm{~N}$ & 7 & - & - & - \\
\hline 116 & $\mathrm{~N}$ & 3.12 & 5 & - & - & - \\
\hline 119 & $\mathrm{~N}$ & $\mathrm{~N}$ & 8 & - & - & - \\
\hline 121 & 0.574 & $\mathrm{~N}$ & 3 & - & - & - \\
\hline 124 & 0.50 & $\mathrm{~N}$ & 4 & - & - & - \\
\hline 125 & 2.7 & 3.3 & 7 & - & - & - \\
\hline 126 & 2.16 & $\mathrm{~N}$ & 6 & - & - & - \\
\hline 130 & 2.7 & $\mathrm{~N}$ & 5 & - & - & - \\
\hline 131 & 0.55 & $\mathrm{~N}$ & 7 & - & - & + \\
\hline 133 & 0.55 & $\mathrm{~N}$ & 3 & - & - & - \\
\hline
\end{tabular}

${ }^{1}$ Optical density from ELISA (Idexx); N, -, negative; +, positive. *fetuses that were less than two months of age were macerated and evaluated using PCR. NO, not obtained.

third trimester $(\mathrm{p}=0.051)$. Comparative analysis on the PCR and serological results revealed that one of the two cows that was PCR-positive was also serologically negative, while the other was seropositive (mean OD $=1.83$ ). Only one (cow no. 131) out of the four cows that had positive fetuses in the PCR analysis was positive in the serological test $(\mathrm{OD}=0.55)$. The serological test revealed three positive fetuses; however, one of the dams was negative in ELISA.

Sixty fetuses were collected for evaluation: 14 were in the first, 28 in the second and 18 in the third trimester of gestation. Additionally, six fetuses were less than two months of age, and serum samples were not obtained from these animals. Thus, 54 serum samples from the fetuses were evaluated, and three (5.5\%) of these samples were serologically positive with high antibody titers $(\mathrm{OD}>3.1)$.

During this study, vertical transmission was demonstrated in $11.6 \%(7 / 60)$ of the fetuses by means of PCR and serological tests.
Cerebral-derived DNA from the fetuses of cow no. 87 and cow N. 111 was positive in PCR analysis. Myocardial-derived DNA from the fetuses of cow no. 74 and cow no. 131 was positive in PCR reactions (Table 2). The DNA-derived blood samples from two cows (animal nos. 13 and 95) were PCR-positive, but only one animal (no. 26) had a corresponding serum titer $(\mathrm{OD}=1.83)$. However, the fetuses of these animals were PCR-negative.

\section{Discussion}

In our study, we investigated vertical transmission of $N$. caninum in dairy cattle slaughtered in southern Brazil. The overall results demonstrated an $N$. caninum vertical transmission rate of $11.6 \%$ (7/60). Three fetuses (3/7) had antibodies that were detected by ELISA (high levels of antibodies) and were $N$. caninum DNA negative in their tissue samples. One dam was serologically negative, and two others had higher antibody titers. Conversely, the other 
fetuses (4/7) were positive for the presence of $N$. caninum DNA in their tissues and were serologically negative, and their dams had low titers of antibodies ( $\mathrm{OD}=0.2$ to 0.5 ). Fluctuations in the results similar to these have previously been described (McINNES et al., 2006; DIJKSTRA et al., 2008; MORÉ et al., 2009; YAO et al., 2009; MARQUES et al., 2011). McInnes et al. (2006) reported that there was no correlation between the serological tests on dams and the PCR on their fetuses, and a high percentage of infected fetuses had serologically negative dams. Moré et al. (2009) showed that transplacental infection in dairy cattle may occur when antibody titers are low in adult cows.

Cabral et al. (2009) used histology, immunohistochemistry and nested-PCR to evaluate 105 aborted fetuses that were sent to the Biological Institute of São Paulo, Brazil, and found a neosporosis rate of $24.8 \%$. In addition, Corbellini et al. (2002) found that $23 \%$ of the aborted fetuses that they collected in Rio Grande do Sul, Brazil, were infected by $N$. caninum. The rate of vertical transmission of neosporosis may vary between cattle herds, and it can range from 4.0 to 100\% (DUBEY; SCHARES, 2011).

Just three cows in the present study had positive blood samples in PCR, in spite of the relatively high prevalence of IgG anti- $N$. caninum in serum samples. Yao et al. (2009) reported that negative PCR results of blood samples did not exclude $N$. caninum infection, which corroborates the observation that few $N$. caninum are present in the blood of intermediate hosts. Additionally, Okeoma et al. (2005) observed greater variation in the concentration of $N$. caninum DNA in blood samples than in heifer brain samples, which indicated that this organ should be chosen for isolating DNA from the parasite.

Therefore, since seronegative dams generate congenitally infected fetuses, the presence or absence of antibodies for $N$. caninum possibly neither supports nor rules out vertical transmission. Yao et al. (2009) stated that seronegative abortion cases should be confirmed by means of PCR analysis on the fetus tissues. The mechanism for Neospora infection in seronegative dams might be explained in terms of: a) early-stage infection; b) the sensitivity of the serological assay (low antibody levels); or c) seronegative conversion in infected cows and immunotolerance of early in-utero infection (McINNES et al., 2006; WILLIAMS; TREES, 2006; YAO et al., 2009). Under natural conditions, most infections caused by $N$. caninum are "in utero", and parasite-induced reactions can be classified as self-infections (as are observed in some viral infections) without producing an immune response.

Previously, Marques et al. (2011) studied vertical transmission in zebu cattle in southern Brazil and found a rate of $4.8 \%$, which is a lower rate than what was observed in the present study (11.6\%). This phenomenon might represent the manifestation associated with each management system, i.e. the difference between having or not having access to infectious sources, nutritional differences and emphasis on production activity (such as milking or weaning), or the variability in the duration of time for which the animals are kept within breeding programs (MARQUES et al., 2011).

The prevalence of $N$. caninum among the cows in the present study was similar to what was described in some previous reports (RAGOZO et al., 2003; SARTOR et al., 2003; LOCATELLI-DITTRICH et al., 2008; BENETTI et al., 2009), but was lower than in other studies (COSTA et al., 2001;
GUIMARÁES JUNIOR et al., 2004; MINERVINO et al., 2008; MUNHOZ et al., 2009; EIRAS et al., 2011). The prevalence of $N$. caninum in dairy cattle in Brazil was previously described as ranging from 15.1 to $91.2 \%$ (LOCATELLI-DITTRICH et al., 2001, 2008; RAGOZO et al., 2003; GUIMARÁES JUNIOR et al., 2004; ). Therefore, caution is needed in evaluating the results from prevalence studies, since the differences in results might be directly related to the serological techniques used, the cutoff values, the sample size or the type (breed and/or species) of animal that is being investigated.

Locatelli-Dittrich et al. (2008) and Munhoz et al. (2009) in Brazil, Wang et al. (2010) and Xia et al. (2011) in China and Eiras et al. (2011) in Spain evaluated anti-N. caninum antibodies in dairy cattle by using ELISA (Idexx). These authors observed a seroprevalence range from 13.3 to $38.2 \%$. Thus, the results obtained from these previous studies might be easier to compare with those from the present study.

In our study, it was difficult to precisely determine whether endogenous or exogenous transmission had higher or lower importance. We could speculate, considering that 5/6 of the $N$. caninum-positive fetuses had $\geq 5$ months of gestation and were almost ready to be born, that endogenous transplacental infection could be considered to be a major infection source for fetuses, but further studies need to be performed to confirm this hypothesis. Bartels et al. (2007) described rates of $44.9 \%$ and $4.5 \%$, respectively, for vertical and horizontal transmission in Dutch dairy herds.

We did not observe any statistical difference between seropositive pregnant (41.6\%) and non-pregnant cows (43.3\%) during this study. This finding could mean that natural immune suppression during the gestational period does not change the prevalence of antibodies against $N$. caninum. The events that occur during pregnancy and the influences of prenatal exposure to the parasite on the development of an immune response are critical issues (INNES et al., 2002) that have to be addressed if the associated mechanism is to be completely understood (WILLIAMS; TREES, 2006).

In conclusion, this study demonstrated a vertical transmission rate for $N$. caninum of $11.6 \%$ in naturally infected pregnant dairy cows in southern Brazil. Additionally, this study was the first description of the occurrence of anti- $N$. caninum antibodies in dairy cattle $(42.5 \%)$ in the state of Santa Catarina.

\section{Acknowledgements}

\section{J.L. Garcia is the recipient of a CNPq fellowship.}

\section{References}

Bartels CJM, Huinink I, Beiboer ML, Van Schaik G, Wouda W, Dijkstra T, et al. Quantification of vertical and horizontal transmission of Neospora caninum infection in Dutch dairy herds. Vet Parasit 2007; 148(2): 83-92. PMid:17640807. http://dx.doi.org/10.1016/j.vetpar.2007.06.004

Benetti AH, Schein FB, Dos Santos TR, Toniollo GH, Da Costa AJ, Mineo JR, et al. Pesquisa de anticorpos anti-Neospora caninum em bovinos leiteiros, cães e trabalhadores rurais da região Sudoeste do Estado de Mato 
Grosso. Rev Bras Parasitol Vet 2009; 18(S1): 29-33. PMid:20040187. http://dx.doi.org/10.4322/rbpv.018e1005

Cabral AD, Camargo CN, Galleti NTC, Okuda LH, Pituco EM, Fava CD. Diagnosis of Neospora caninum in bovine fetuses by histology, immunohistochemistry, and nested-PCR. Rev Bras Parasitol Vet 2009; 18(4): 14-19. PMid:20040203. http://dx.doi.org/10.4322/ rbpv.01804003

Corbellini LG, Driemeier D, Mori AM, Traverso SD. Evaluation of Neospora caninum-associated abortion storm in a dairy herd in Santa Catarina, Brazil. Rev Bras Reprod Animal 2001; 25(2): 258-259.

Corbellini LG, Driemeier D, Cruz CFE, Gondim LFP, Wald V. Neosporosis as a cause of abortion in dairy cattle in Rio Grande do Sul, southern Brazil. Vet Parasitol 2002; 103(3): 195-202. http://dx.doi. org/10.1016/S0304-4017(01)00600-8

Costa GHN, Cabral DD, Varandas NP, Sobral EA, Borges FA, Castagnolli KC. Frequence of antibodies for Neospora caninum and Toxoplasma gondii in cattle, São Paulo and Minas Gerais States. Semina: Cienc Agrar 2001; 22(1): 61-66.

Dijkstra T, Lam TJGM, Bartels CJM, Eysker M, Wouda W. Natural postnatal Neospora caninum infection in cattle can persist and lead to endogenous transplacental infection. Vet Parasitol 2008; 152(3-4): 220-225. PMid:18280662. http://dx.doi.org/10.1016/j.vetpar.2007.12.034

Dubey JP, Schares G. Diagnosis of bovine neosporosis. Vet Parasitol 2006; 140(1-2): 1-34. PMid:16730126. http://dx.doi. org/10.1016/j.vetpar.2006.03.035

Dubey JP, Schares G. Neosporosis in animals - The last five years. Vet Parasitol 2011; 180(1-2):90-108. PMid:21704458. http://dx.doi. org/10.1016/j.vetpar.2011.05.031

Eiras C, Arnaiz I, Álvarez-García G, Ortega-Mora LM, Sanjuánl ML, Yusc E, et al. Neospora caninum seroprevalence in dairy and beef cattle from the northwest region of Spain, Galicia. Prev Vet Med 2011; 98(2-3): 128-132. PMid:21145605. http://dx.doi.org/10.1016/j.prevetmed.2010.10.014

Guimarães Junior JS, Souza SLP, Bergamaschi DP, Gennari SM. Prevalence of Neospora caninum antibodies and factors associated with their presence in dairy cattle of the north of Paraná state, Brazil. Vet Parasit 2004; 124(1-2): 1-8. PMid:15350656. http://dx.doi. org/10.1016/j.vetpar.2004.07.002

Innes EA, Andrianarivo AG, Björkman C, Williams DJ, Conrad PA. Immune responses to Neospora caninum and prospects for vaccination. Trends Parasitol 2002; 18(11): 497-504. http://dx.doi.org/10.1016/ S1471-4922(02)02372-3

Locatelli-Dittrich R, Machado Junior PC, Fridlund-Plugge N, Richartz RRTB, Montiani-Ferreira F, Patricio LFL, et al. Determinação e correlação de anticorpos anti-Neospora caninum em bovinos e cães do Paraná, Brasil. Rev Bras Parasitol Vet 2008; 17(S1): 191-196. PMid:20059847.

Locatelli-Dittrich R, Soccol VT, Richartz RRTB, Gasino-Joineau ME, Vinne R, Pinckney RD. Serological diagnosis of neosporosis in a herd of dairy cattle in southern Brazil. J Parasitol 2001; 87(6): 1493-1494. PMid:11780849.

Marques FAC, Headley SA, Figueredo-Pereira V, Taroda A, Barros LD, Cunha IAL, et al. Neospora caninum: evaluation of vertical transmission in slaughtered beef cows (Bos indicus). Parasitol Res 2011; 108(4): 1015-1019. PMid:21063729. http://dx.doi.org/10.1007/s00436-010-2146-x

McInnes LM, Ryan UM, O’Handley R, Sager H, Forshaw D, Palmer DG. Diagnostic significance of Neospora caninum DNA detected by PCR in cattle serum. Vet Parasitol 2006; 142(3-4): 207-213. PMid:16934934. http://dx.doi.org/10.1016/j.vetpar.2006.07.013

Minervino AHH, Ragozo AM, Monteiro RM, Ortolani EL, Gennari SM. Prevalence of Neospora caninum antibodies in cattle from Santarém, Pará, Brazil. Res Vet Sci 2008; 84(2): 254-256. PMid:17619028. http:// dx.doi.org/10.1016/j.rvsc.2007.05.003

Moré G, Bacigalupe D, Basso W, Rambeaud M, Beltrame F, Ramirez B, et al. Frequency of horizontal and vertical transmission for Sarcocystis cruzi and Neospora caninum in dairy cattle. Vet Parasitol 2009; 160(1-2): 51-54. PMid:19070964. http://dx.doi. org/10.1016/j.vetpar.2008.10.081

Muller N, Zimmermann V, Hentrich B, Gottstein B. Diagnosis of Neospora caninum and Toxoplasma gondii infection by PCR and DNA hybridization immunoassay. J Clin Microbiol 1996; 34(11): 2850-2852.

Munhoz AD, Pereira MJS, Flausino W, Lopes CWG. Neospora caninum seropositivity in cattle breeds in the South Fluminense Paraíba Valley, state of Rio de Janeiro. Pesq Vet Bras 2009; 29(1): 29-32. http://dx.doi. org/10.1590/S0100-736X2009000100004

Okeoma CM, Stowell KM, Williamson NB, Pomroy WE. Neospora caninum: Quantification of DNA in the blood of naturally infected aborted and pregnant cows using real-time PCR. Exp Parasitol 2005; 110(1):48-55. PMid:15804378. http://dx.doi. org/10.1016/j.exppara.2005.01.008

Ragozo AMA, Paula VSO, Souza SLP, Bergamaschi DP, Gennari SM. Ocorrência de anticorpos anti-Neospora caninum em soros bovinos procedentes de seis estados brasileiros. Rev Bras Parasitol Vet 2003; 12(1): 33-37.

Sartor IF, Hasegawa MY, Canavessi AMO, Pinckney RD. Ocorrence of Neospora caninum antibody in dairy cows assayed by ELISA and IFAT from Avaré county, SP Semina: Cienc Agrar 2003; 24(1): 3-10.

Schares G, Peters M, Wurm R, Bärwald A, Conraths FJ. The efficiency of vertical transmission of Neospora caninum in dairy cattle analysed by serological techniques. Vet Parasitol 1998; 80(2): 87-98. http://dx.doi. org/10.1016/S0304-4017(98)00195-2

Trees AJ, Williams DJL. Endogenous and exogenous transplacental infection in Neospora caninum and Toxoplasma gondii. Trends Parasitol 2005; 21(12): 558-561. PMid:16223599. http://dx.doi. org/10.1016/j.pt.2005.09.005

Xia HY, Zhou DH, Jia K, Zeng XB, Zhang DW, She LX, et al. Seroprevalence of Neospora caninum Infection in Dairy Cattle of Southern China. J Parasitol 2011; 97(1): 172-173. PMid:21348632. http://dx.doi. org/10.1645/GE-2643.1

Wang C, Wang Y, Zou X, Zhai Y, Gao J, Hou M, et al. Seroprevalence of Neospora caninum Infection in Dairy Cattle in Northeastern China. J Parasitol 2010; 96(2): 451-452. PMid:19895158. http://dx.doi. org/10.1645/GE-2310.1

Williams DJL, Trees AJ. Protecting babies: vaccine strategies to prevent foetopathy in Neospora caninum-infected cattle. Parasite Immunol 2006; 28(3): 61-67. PMid:16441503. http://dx.doi. org/10.1111/j.1365-3024.2005.00809.x

Yao L, Yang N, Liu Q, Wang M, Zhang W, Qian WF, et al. Detection of Neospora caninum in aborted bovine fetuses and dam blood samples by nested PCR and ELISA and seroprevalence in Beijing and Tianjin, China. Parasitology 2009; 136(11): 1251-1256. PMid:19660160. http:// dx.doi.org/10.1017/S0031182009990813 